This is an author produced version of a paper published in Journal of Philosophy of Education. This paper has been peer-reviewed but does not include the final publisher proof-corrections or journal pagination.

Citation for the published paper:

Lilja, Peter; Dahlbeck, Johan. (2019). In the Absence of Adults : Generations and Formation in Hunt for the Wilderpeople. Journal of Philosophy of Education, vol. 53, issue 2, p. null

URL: https://doi.org/10.1111/1467-9752.12350

Publisher: Wiley

This document has been downloaded from MUEP (https://muep.mah.se) / DIVA (https://mau.diva-portal.org). 


\title{
In the Absence of Adults: Generations and Formation in Hunt for the Wilderpeople
}

\author{
Peter Lilja \& Johan Dahlbeck \\ Malmö University
}

\begin{abstract}
Taika Waititi's recent film Hunt for the Wilderpeople (2016) portrays the coming-of-age of a young boy, Ricky, in a world with few recognizably responsible adults. While the film does not engage explicitly with formal education, it raises several questions central for understanding education as formation, highlighting the generational aspects of educational relations and pointing to the importance of an adult world taking responsibility for the formation and upbringing of the younger generation. Departing from a discussion on the role of formation and intergenerational relations in Rousseau and Arendt, we will draw on the film's portrayal of an adult world in crisis in order to discuss some of its possible consequences for understanding education in terms of intergenerational relations and formation. This involves raising questions about the educational consequences of the absence of recognizably responsible adults and it involves investigating how this absence might impact our understanding of education as the formation and upbringing of educated human beings.
\end{abstract}

Keywords: Generation, Education, Formation, Rousseau, Arendt, Hunt for the Wilderpeople

We are born weak, we need strength; we are born totally unprovided, we need aid; we are born stupid, we need judgement. Everything we do not have at our birth and which we need when we are grown is given us by education. $(E .1, p .38)^{1}$

\section{Introduction}

Education has always been concerned with intergenerational relations and the fostering of young people has always been a matter of philosophical controversy. Whether or not education is conceived as inherently child-centered or subject/adult-centered, the formation of the new generation is at the heart of educational accounts from antiquity, through the Enlightenment, to modern society. For Plato, the goal was to align educational formation with the demands of the Republic, his ideal adult society. For Kant, it was aimed at the creation of the cosmopolitan human and for Dewey, it served the purpose of democratic society. As different as these ideas are, they

\footnotetext{
${ }^{1}$ Rousseau's Emile (1979) will be cited as E followed by book number and page for all subsequent references.
} 
all coalesce in the acknowledgement that education concerns the transition from childhood to adulthood and from ignorance to ethical maturity in one way or another.

The history of educational ideas illustrates that the educational formation of children is intimately connected to the formation of ideal society, and thus to political thought. Depending on the trajectory of political ideas, notions of formation take on very different qualities. While two important political thinkers such as Jean-Jacques Rousseau and Hannah Arendt both focus on intergenerational aspects of education, they present very different paths to the formation of responsible adults. For Rousseau, having little or no trust in teachers as representatives of society, education starts out as a purely negative endeavor. Thus, 'it consist not at all in teaching virtue or truth, but in securing the heart from vice and the mind from error' (E.2, 93). While early years education, as conceived by Rousseau, is focused entirely on the present, his greater progressive political project aims at the establishment of the society of the General Will, where the educated adults freely recognize their common interests and, based on that recognition, join in a common body politic (Cohen 2010). For Arendt, recognizing the natural authority of adults and teachers, education becomes a positive endeavor aiming at the introduction of new generations to an old world. Arendt's educational conservatism aims for the preservation of the future political agency of the new generation, what she terms their natality. 'Exactly for the sake of what is new and revolutionary in every child, education must be conservative', she writes (Arendt 2006, 189). While Rousseau's political ideal hinges on the uniformity of the General Will and Arendt's on the plurality of the public sphere, they are both arguing, in different ways, for the need of education as formation of responsible and autonomous adults.

Since the mid-1900s, educational policy and practice have been heavily influenced by what Darling and Nordenbo (2003) call "progressivism" in a trivial sense. In this sense, progressivism does not describe a coherent school of thought but rather a set of commonly accepted educational tenets, including the ambition 'to consider the child's nature, to care for learnercenteredness, to adapt the lessons to the child's "natural" motivation, to promote children's personal growth and creativity' (p. 305). In the turn towards child-centered education, the question of teacher authority becomes highly contested. As Kitchen (2014, 42) argues, in contemporary progressive education ' $t$ ] here is no place for any form of authority and no belief in what authority represents'. Destabilizing the natural authority of adult figures may be taken to undermine the responsibility of the older generation for introducing the new generation to the world. Rather, children are supposed to discover it themselves. As we have argued elsewhere (Authors), the erosion of adult authority in education has coincided, and even aligned, with the overall commodification of education resulting from the erosion of the traditional welfare state. As Biesta $(2005,57)$ argues, 'the relationship between governments and citizens has in many cases changed into a relationship between the state as provider of public services and taxpayers as consumers of these services'. Somewhat surprisingly, the progressive ideal of childcenteredness seems to lend itself well to the economic idea of the student as a consumer on an educational market. From this perspective, adult authority is called into question by two very different currents in contemporary society: the progressive ideal of child-centeredness and the 
displacement of traditional child-adult relations brought about by the commodification of education. In so far, then, as education is inevitably bound up with formation through intergenerational relations, one might legitimately wonder what happens when the tasks and responsibilities of the older generation are called into question?

In this article, we would like to explore the notion of education as formation and upbringing in relation to the influential contemporary understanding of education as primarily aimed at 'supporting or facilitating learning' (Biesta, 2005, p. 55). Biesta's discussion of the 'learnification' of education highlights a shift from education as an intergenerational exchange aimed at the formation of those to be educated, to an economic exchange where focus is placed on the providers and consumers of educational services rather than on the transformational potential of the educational experience itself. One of the problems with describing education in terms of an economic transaction is that this appears to presuppose a relation in which the consumer/student is assumed to already 'know what their needs are and that they know what they want' (p. 58), whereas education as formation demands a teacher responsible for introducing the child/student to a world of which they know very little. Education as formation, understood in this sense, demands a teacher capable of, and willing to, assume responsibility for the educational transition from childhood to adulthood. This, in turn, requires an adult world equipped for meeting this demand.

Taika Waititi's recent film Hunt for the Wilderpeople (2016) portrays the coming-of-age of a young boy, Ricky, in a world with few recognizably responsible adults. While the film does not engage explicitly with formal education, it raises several questions central for understanding education as formation, highlighting the generational aspects of educational relations and pointing to the importance of an adult world taking responsibility for the formation and upbringing of the younger generation. Rather than offering a rigorous analysis of the film - as a fictional account of formation - we aim to engage in a conversation with the film about the questions it raises concerning the role of intergenerational relations in education. As such, we will draw on the film's portrayal of an adult world in crisis in order to discuss some of its possible consequences for understanding education in terms of intergenerational relations and formation. This involves raising questions about the educational consequences of the absence of recognizably responsible adults and it involves investigating how this absence might impact our understanding of education as the formation and upbringing of educated human beings.

Hunt for the Wilderpeople borrows its narrative structure from the traditional Bildungsroman. It tells the story of young Ricky's maturation and formation from his arrival at his latest foster home to his escape and exile into the New Zealand bush, and finally, his return to society as a transformed person willing to accept the rules of society. Throughout Ricky's ordeals, he is confronted with representatives of the adult world, some helpful and others less so, portrayed in a satirical and exaggerated way. Even though the film is clearly a satire poking fun at the adult world of contemporary society, it is at the same time faithful to the literary genre of the Bildungsroman. While the Bildungsroman may be understood in terms of two different traditions, 
one could argue that Hunt for the Wilderpeople borrows traits from both. In Buckley's Season of Youth: The Bildungsroman from Dickens to Golding (1974, p. 18) the characteristics of the British Bildungsroman are listed as follows: 'childhood, the conflict of generations, provinciality, the larger society, self-education, alienation, ordeal by love, the search for a vocation, and a working philosophy'. Most, if not all, of these themes are dealt with explicitly in the film. In the German tradition, however, the Bildungsroman denotes novels 'that featured self-involved protagonists who withdraw from active engagement with the social world' (Boes 2006, p. 232). Throughout much of the film, the formation of Ricky takes place in the New Zealand bush, in a self-chosen exile from the threats of civilization. The plot of the film is organized in ten discrete chapters and an epilogue, with title cards describing the different stages of Ricky's formation from chapter one's 'A real bad egg' to the climax of the final chapter, titled 'War'. In this sense, the film is informed by the German tradition as far as the German Bildungsroman typically features a regular development of the life of the individual where 'each of the stages has its own intrinsic value and is at the same time the basis for a higher stage' (Dilthey 1985, p. 390). Correspondingly, each of the chapters of the film introduces a new phase predicated by the development of the previous. It is the combination of the traditional structure of a Bildungsroman and the satirical portrayal of the modern world that highlights important questions for the philosophy of education. What is particularly interesting about Hunt for the Wilderpeople is that the satirical portrayal of the adult world helps us accentuate and discuss a fundamental tension within contemporary education concerning the complex relation between adults and children.

In what follows, we will begin by fleshing out and substantiating our understanding of education as formation. Using Rousseau's Emile as a paradigmatic example, we argue that education as formation necessarily entails a process of ethical maturation that requires the guidance of a selfsufficient adult qua teacher. Becoming an adult, in this sense, is more concerned with becoming an educated person than with growing older. Next, we turn to an Arendtian critique of the dismantling of traditional authoritative relations between children and adults, in order to help explain the absence of responsible adults in the wake of progressivism and the commodification of education. In 'The Crisis in Education' (2006) Arendt connects her critique of the progressive image of an autonomous world of childhood to the disruption of education as the introduction of a new generation into an old world. In doing so, she underlines the importance of education as a process of formation, where those to be educated are necessarily guided by those already educated.

Having sketched the tension between education as formation and Arendt's critique of modern intergenerational relations, we turn to the film Hunt for the Wilderpeople. Using the satirical portraits of adult characters in the film, we aim to illustrate some possible educational consequences of the absence of responsible adults from the public sphere. We will also use the depiction of the changing relationship between the main characters, Ricky and Hec, in order to discuss the potentials of framing education as a process of formation, despite the difficulties posed by the contemporary educational landscape. 
In the final section, we will argue for the benefits of understanding and conceptualizing education as formation in a context of an educational system characterized by what Biesta (2005) calls 'learnification', resulting in a dismantling of the role of the teacher in the sense of a responsible adult charged with the task of introducing the younger generation to the world.

\section{Education as formation in Rousseau's Emile}

Conceived broadly, education for Rousseau concerns the artificial transformation of natural man into civil man. This process of formation reveals Rousseau's ambition to formulate a vision of how society might be transformed through education. Famously, in the first lines of The Social Contract, Rousseau asserts that ' $\mathrm{m}$ ] an is born free, and everywhere he is in chains' (2012, p. 163). The chains that bind him are not forged from steel, but from the opinions of others. In his own time, Rousseau despaired over the inability of most people to recognize and act on their true needs, alienating them from themselves and leaving them helpless in the face of destructive external influences. A good society, Rousseau suggests, is made up of individuals who are selfsufficient and who love themselves before they are capable of entering into a 'common unity, with the result that each individual believes himself no longer one but a part of the unity [...]' (E.1, p. 40). When such unity is established, Rousseau's ideal society - ruled by the General Will of the people - may come into being. According to Cohen (2010, p. 15), '[i]n the society of the general will, citizens share an understanding of the common good and that understanding is founded on the members' commitment to treat one another as equals by refraining from imposing burdens on other citizens that those members would be unwilling to bear themselves'. For Rousseau, this means that education, initially, 'ought to be purely negative' (E.2, p. 93) so as not to stifle the autonomy necessary for establishing the society of the General Will.

For Rousseau, 'what makes man essentially good is to have few needs and to compare himself little to others; what makes him essentially wicked is to have many needs and to depend very much on opinion' (E.4, p. 214). Education as formation concerns the endeavor to create individuals capable of withstanding the corrupting influences of social life. This is not a natural process, but an active intervention thwarting the human tendency to be governed by passions such as anger, pride, vanity and jealousy. These inhibiting passions are believed to be reinforced and strengthened by a kind of 'positive' education primarily aimed at preserving society such as it is (Plamenatz, 1972). The first task of education must therefore be to allow the child to develop a kind of self-love (amour de soi) preventing him from being 'plagued by fears of what may befall him or desirous of goods he cannot attain, [but where] he is happy in the present' (Nichols 1985, p. 535). Because people are prone to impose their own will upon others, Rousseau concludes that the child's first teacher must be nature rather than man. This way, the teacher's task is not to actively impart knowledge about the world but to allow nature to run its course, so that 'by doing nothing, you would have worked an educational marvel' (E.2, p. 94). It is not that education as formation is unnecessary, but that without a robust sense of self-love, children are easily led into a kind of bondage of the passions preventing them from becoming truly autonomous. Rousseau 
laments that much of early education, in reality, is misdirected in so far as it attempts to teach that which does not need teaching. He asks: 'How many people [...] does one see walk badly for their whole life because they were badly taught how to walk?' (E.2, p. 78). The task of the teacher, then, becomes to protect the young child from the social world, so that self-love can grow uninhibited and at the same time to refrain from intervening with the sometimes painful education of nature. In line with this, one of the teacher's most important principles becomes that of maintaining self-control in relation to the child's natural development. As Rousseau notes, when a child falls and is hurt, a parent or teacher's intuitive response is generally to run to its aid. In doing so, however, or so Rousseau claims, the child is robbed of the valuable lesson of falling and getting up again. Instead, the child is taught to act in accordance with external expectations so that the pity of the parent or teacher becomes a cause for satisfaction, but one that leads to dependence rather than independence. Hence, 'to suffer is the first thing he [Emile] ought to learn and the thing he will need the most' (E.2, p. 78). As Jonas (2010, p. 51) notes, '[i]f the tutor acquiesces to the feelings of pity regarding Emile's immediate pain he will lose the ability to properly educate him. The tutor must use his self-mastery to overcome these feelings of pity so that he can act justly'.

Whereas this kind of 'negative' education is necessary for allowing the child to gain sufficient selfknowledge there comes a time when the child becomes an adolescent and mature enough for a more 'positive' education. For Rousseau, as 'man in general is not made to remain always in childhood' (E.4, p. 211), with puberty, '[i]t is therefore time to change method' (E.4, p. 215). Allowing the young child to learn how to live fully in the present, well aware of its capabilities and limitations, Rousseau believes that a sound sense of judgment develops naturally. Once this kind of judgment is in place, the young person is ready to apply it to the knowledge about the world offered by the teacher in a manner that is both 'disinterested and without passion' (E.4, p. 237). Even though this part of Emile's education is more 'positive', and the teacher's role more pronounced, it is still pivotal that the teacher restrains from letting his own judgments overshadow Emile's (Tröhler 2012). Accordingly, Rousseau writes: 'The worst historians for a young man are those who make judgments. Facts! Facts! And let him make his own judgments. It is thus that he learns to know men. If the author's judgment guides him constantly, all he does is see with another's eye; and when that eye fails him, he no longer sees anything' (E.4, p. 239).

On a critical note, Rousseau's ideal of self-sufficiency places restraints upon the teacher that severely restricts the kind of intergenerational influence otherwise central to many understandings of education as formation. ${ }^{2}$ Arguably, for a teacher not to impose judgment or will, is to denounce a vital part of the role of the teacher. As Winch (1996, p. 419) notes, Rousseau 'does not consider that the overt imposition of one will upon another could be beneficial and hence natural in his sense in precisely those situations in which it was done, not to gratify a sense

\footnotetext{
${ }^{2}$ Rousseau's ideas of 'negative' education, intended to safeguard the autonomy of the child, has met with extensive critique. For example, Yonah (1993, p. 229) remarks that it 'has been denounced as outright manipulation in disguise'.
} 
of power or domination, but in order to further the interests of the individual imposed upon. Rousseau's failure to see that this could happen in a non-corrupting way is one of the major obstacles to accepting his account of learning or, indeed, of teaching'. Nevertheless, it is clear that the Rousseauian child needs to be guided by an autonomous adult, one who has already cultivated the proper self-love and self-sufficiency required for taking part in the society of the General Will. The great paradox for education, then, is that 'an autonomous and self-governing people must be taught to be autonomous and self-governing' (Villa 2017, p. 29).

In sum, education for Rousseau is fundamentally about the transformation of society through the transformation of individuals. As such, '[e]ducation is always directed to a political whole' (Tröhler 2011, p. 74). Without this process of formation, Rousseau claims that we will remain weak, unprovided and ignorant. Consequently, children need to be educated in the arts of selfsufficiency and self-love in order to become active and morally responsible persons, rather than passive victims of the opinions of others. At the heart of this, is the need for adults, capable of and willing to take responsibility for guiding children through the process of developing autonomy. As such, while Rousseauian education is decidedly child-centered, it is thoroughly dependent upon a clear distinction between what it means to be a fully formed person and a person in need of education. Education, therefore, is always about becoming something else, even if parts of this process entails the realization that education must take time and that, in the words of Rousseau, the most useful rule of education is that '[i]t is not to gain time but to lose it' (E.2, p. 93).

One of Rousseau's harshest critics in terms of his espousal of education as a means for transforming society, and in extension of the Rousseauian conception of a good teacher, is Hannah Arendt. In the next section, we turn to Arendt's critique of educational systems designed to hand over responsibility for the future on the next generation, so as to broaden our conception of formation and narrow in more pronouncedly on the importance of intergenerational relations in education.

\section{Arendt on Adult Responsibility in Education}

While Rousseau is often credited as one of the founding fathers of progressive education (Darling, 1994), the understanding of child and adult-relations - and thereby the pedagogical relation between teacher and child ${ }^{3}$ - has undergone a radical transformation within contemporary progressive education through a wider reconceptualization of childhood since the early $1900 \mathrm{~s}$ (Mintz, 2012). In Arendt's understanding, the tenets of progressive education - coupled with the influence of modern psychology - changed the relationship between children and adults so that ' $[t]$ he very thing that should prepare the child for the world of adults, the gradually acquired habit of work and of not-playing, [was] done away with in favor of the autonomy of the world of childhood' (Arendt, 2006 p. 180). In this setting, the modern attunement to the idea that 'the child's interests and developmental maturity are to limit and guide all instruction', and that all

\footnotetext{
${ }^{3}$ For a helpful historical treatment of how the pedagogical relation has been construed and challenged within educational theory, see Friesen (2017).
} 
'genuine learning is exciting and pleasurable' (Mintz, 2012 p. 249), meant that the role of pain, central to Rousseau's understanding of a natural education, was downplayed in order to come to terms with the inherent asymmetry of traditional educational relations. In the attempt to level out the asymmetry of education, the traditional understanding of a pedagogical relation underwent radical changes. Drawing on Herman Nohl's conception of the pedagogical relation within a German pedagogical tradition, Friesen (2017, p. 182) notes that '[t]he child and adult do not meet as equals in such an "intentional" relation; they obviously are not friends who are together for their mutual benefit'. Whereas the adult's point of view is characterized by love and authority, the point of view of the child is one characterized by love and obedience. Since this relation 'cannot be forced, but [...] is entered into freely by both educator and educand [...] [i]t proceeds as much from the authority of the adult as from the freedom of the child' (p. 183). Nohl's understanding of the pedagogical relation is very much present as a starting point for Arendt's critique of the influence of progressivism on modern American education.

Observing the early signs of the emergence of the modern child, emancipated from the influence of adults through progressive education, Hannah Arendt reflected on the inherent problems of decoupling the world of childhood from the world of adulthood and the related idea of the autonomous child. Understanding education as part of the political sphere and consisting of equal democratic relations presupposes, in Arendt's view, that the social world of childhood is autonomous and independent of adult authority. The problem with this assumption, as Arendt perceives it, is that the 'real and normal relations between children and adults, arising from the fact that people of all ages are always simultaneously together in the world, are thus broken off' (Arendt 2006, p. 178). A consequence of this is that without the guidance of adults, children are left to the tyranny of their own group, leaving them without shelter from popular opinion, and paradoxically that the educationally important hierarchy between children and adults is dismantled. Furthermore, Arendt claims that construing children as already political robs them of their chances of actually forming their own political future. For Arendt, the preparation and formation of children for the public world is precisely the purpose of education. She asks: 'How could it happen that the child was exposed to what more than anything else characterized the adult world, its public aspect, after the decision had just been reached that the mistake in all past education had been to see the child as nothing but an undersized grown-up?' (p. 184). The problem Arendt points to has to do with the fact that the progressive political emancipation of children assumes that children are naturally equipped for the public world of politics, whereas she believed that 'in politics we always have to deal with those who are already educated' ( $p$. 173). Including the uneducated into politics, Arendt warns, may result in an increase in worldalienation instead of political action. ${ }^{4}$

For Arendt, education is fundamentally about the introduction of new generations to an old world. This introduction requires adults willing to take responsibility for the world by offering knowledge about it. The role of the teacher, as a representative of the world, is to accept the authority to impart knowledge so that the new generation comes to know the world into which

\footnotetext{
${ }^{4}$ For a detailed discussion on the relationship between education and world-alienation see Levinson (2010).
} 
they have been born in order to renew it. In contrast with modern progressivism, Arendt denies that this renewal can take place within education itself, as education, for Arendt, is conceived as a protected space between the private and public spheres of human existence. Whereas Rousseau harbored a deep mistrust of the teacher's ability to introduce young children to the world via instruction, but turned instead to nature, Arendt argues for the necessity of studying human culture in order to be able to renew it. For teachers to denounce the responsibility to accept authority in the pedagogical relation is to 'refuse to take responsibility for the world into which they have brought their children' (Arendt 2006, p. 187). One of the tendencies, identified by Arendt, in terms of the adult world's refusal to accept responsibility was the establishment of what she called an autonomous world of childhood, where adults, as figures of authority, are absent. As Euben (2001, p. 198n) argues:

Since it is adults who establish this separate world of children, its very existence indicates, at the very least, an abdication of responsibility for educating children into adulthood. It may even be regarded as a statement of confusion, indifference, or contempt by adults for their world or, more disconcertingly, as an unstated desire to be children, thereby renouncing the privileges and responsibilities of the world as it exists.

While Arendt and Rousseau have very different understandings of the intergenerational relations in education, they both stress the necessity of an artificial process of formation where 'the natural man' or 'the newcomer' is transformed into a morally responsible human being. Canovan argues that Rousseau 'made a sharp distinction between "man" and "citizen", stressing that whereas the one is natural, the other is artificial and operates according to man-made rules.' Similarly, Arendt's 'point was that equality and rights which men do not possess by nature, and which are not naturally respected by others, exist (where they exist at all) strictly as human constructs, because men have joined together to create institutions that will secure them' (Canovan 1983, pp. 288-289). Human freedom, for both Rousseau and Arendt, therefore presupposes education in so far as political participation requires a cultivated understanding of oneself and the world. While both aim for the cultivation of a responsible citizen, they differ in their understanding of how this formation is to be staged. For Rousseau, the positive formation of the citizen starts after puberty through the teaching of 'history and political principles' (Tröhler 2011, p. 74). For Arendt, in contrast, all of education aims at developing an understanding of the world necessary for future political action.

Having sketched out Rousseau's and Arendt's notions of formation and the tensions between them, we will now set up an educational conversation with the film Hunt for the Wilderpeople in order to draw conclusions about the potential of education as formation in a contemporary society portrayed in the film as characterized by bureaucratization and the absence of adults. Because we understand the film as a satirical version of a Bildungsroman, it offers a good opportunity to raise questions about formation in the light of social critique. To start off, we will investigate the theme of the absence of adults, drawing on the satirical portrayal of adult figures 
to highlight problematic aspects of the changing landscape of intergenerational relations. Second, we will focus on the mutual formation of the film's main characters in order to discuss the centrality of conceiving formal education in terms of formation. Finally, we will conclude the article by returning to the questions raised in the introduction.

\section{The absence of adults in Hunt for the Wilderpeople}

Ricky Baker is an unwanted product of society. He is 'a real bad egg. [...] We are talking disobedience, stealing, spitting, running away, throwing rocks, kicking stuff, defacing stuff, burning stuff, loitering and graffiti.' This is how Ricky is described by Paula, a representative of New Zealand's Child Welfare Services as he is dropped off at the rural home of Bella and Hec, his latest foster family. Hunt for the Wilderpeople is a contemporary coming of age-film portraying the maturation of Ricky, a thirteen-year-old boy in the care of Bella, a nurturing and idealistic woman with inclinations towards progressive education, and $\mathrm{Hec}$, a natural man (in the Rousseauian sense) rejected and withdrawn from society. In the setting of the New Zealand bush, the authorities believe that the 'change in scene will help straighten him out'. When Bella unexpectedly dies one day, the real journey for Ricky begins. Running from the authorities, Ricky and Hec embark upon a transformative quest through the wilderness, a quest that will change both of them in fundamental ways.

Throughout the film, Ricky encounters a series of satirical representations of adults. While these characters are grown-ups, they come nowhere near living up to the ideals of what either Rousseau or Arendt would consider morally responsible human beings. Paula, from the Child Welfare Services, is the archetypical bureaucrat, more concerned with enforcing rules than tending to Ricky's needs. Always adhering to her own slogan 'no child left behind' she is determined to track down Ricky in order to 'rescue' him from Hec and to save him from an upbringing outside of social institutions. Paula will spare no means to reinstate Ricky into an existing social order (that has already corrupted him). The aim is not to ensure that Ricky becomes self-sufficient and self-loving, but rather to make him a passive and compliant part of society. Paula's understanding of a model citizen is a person who obeys rules motivated either by the fear of disciplinary sanctions or the hope of temporary rewards. In this, she becomes a kind of personification of the corrupting forces of a society governed by blind obedience, lack of personal judgment, compassion and understanding of the value of true needs.

Hec, Ricky's reluctant guardian following the untimely demise of Bella, is in many ways the opposite of Paula. Hec is portrayed as an example of the 'natural man.' Introduced as a 'bushman' he is guided by the virtue of self-sufficiency and has actively turned his back on society. While he is intuitively familiar with what is required to satisfy his own needs in nature, he is unable to understand and communicate his inner life with other people. Having already failed in society (Hec is an ex-convict who has exiled himself from the company of others), he wants nothing more than to live out his life in solitude. His main driving force is to avoid responsibility and to stay as far away as possible from the demands (and potential hurt) of social life. While he is self-sufficient, he is driven by contempt rather than self-love, hindering him from reentering society. 
Having been on the run for several months, Ricky and Hec encounter a ranger in need of medical assistance. Being unable to resolve the situation themselves, they decide to have Ricky locate help from the outside world. Ricky reaches out to Kahu, a young girl, and her father TK, living on the outskirts of the bush. TK and Kahu are father and daughter, but it soon becomes clear that their relationship is oddly reversed. While Kahu is portrayed as rational and levelheaded, TK is in many ways a big child. His first impulse upon encountering Ricky, whom he recognizes from the local news, is to take a series of selfies with him in order to impress his friends. TK is caught up with and fascinated by the media image of Ricky as a run-away outlaw and instead of interacting with Ricky as an adult relating to a young boy, he relates to him as an equal, in the sense that he himself is more a boy than a man. This is evident from TK's parting words: 'You're the man for me. You're a boy, but you are a man. Bro. I love you Ricky.' In being unable to interact as an adult with Ricky, he becomes a representative of a generation of adults that have never matured into adulthood in Rousseau's sense (Quill 2011), and in an Arendtian sense, he is part of an adult community with 'an unstated desire to be children' (Euben 2001, p. 198n).

The final example we have chosen from Ricky's encounters with the adult world is Psycho Sam, a paranoid and conspiratorial recluse on the run from 'the machine' of society and its ever-present 'form-fillers.' He identifies with Ricky and Hec as fellow victims of the oppressive bureaucracy, represented in the film by Paula and the authorities. In his irrational rantings about the many wrongs of the Government, Sam exhibits an intuitive understanding of a society gone awry. However, his lack of knowledge about the world prohibits him from productively turning his political agenda into action beyond his irrational behavior of, for example, wearing a steel colander for a hat in order to prevent the Government from intercepting his thoughts. While Sam's fundamental distrust of bureaucracy as an obstacle for human freedom is confirmed by both Arendt's and Rousseau's diagnoses of society's ailments, he lacks any of the tools necessary for engaging in a collective endeavor to reconstitute society. As a result, his only option is to exile himself from society and to give up his claims as an active citizen.

These examples illustrate the absence of adults capable of providing role models for the younger generation and for assuming responsibility for their formation. The adult positions depicted in the film and described above are limited to the unreflective bureaucrat, the self-loathing loner, the irresponsible man-child, and the anti-social recluse. Neither of these seem to offer the kind of guidance that both Arendt and Rousseau require from responsible adults. In Arendt's case, being a responsible adult means to take joint responsibility for and represent the world as it is. It is to 'stand in relation to the young as representatives of a world for which they must assume responsibility although they themselves did not make it, and even though they may, secretly or openly, wish it were other than it is' (Arendt 2006, p. 186). Lacking the necessary judgment to think independently, Paula's attempt at taking responsibility fails as her only rationale for action is blind rule following. Hec, TK and Sam, in different ways, all refuse to take responsibility for the world by trying to exclude themselves from the public sphere where all political action take place. 
For Rousseau, a morally responsible adult is guided by his own rationality and self-knowledge, granting him a degree of independence from the forces of the social world of which he must be a part. Being self-sufficient, like $\mathrm{Hec}$, may suffice for the natural man. However, for Rousseau 'the object is not, for all that, to make him [the young person] a savage and to relegate him to the depths of the woods.' The role of the adult is to help insure that the maturing person 'not let himself get carried away by either the passions or the opinions of men, that he see with his eyes, that he feel with his heart, that no authority govern him beyond that of his own reason' (E.4, $p$. 255). In relation to Ricky, neither TK nor Paula can offer any guidance beyond the reliance on the opinions of others or the shallow authority of a bureaucratic social system. Having turned their backs on society, neither Hec nor Sam can offer any guidance beyond the New Zealand bush, leaving Ricky vulnerable and unprepared for reentering society.

Through these satirical portraits of insufficient adults, Hunt for the Wilderpeople illustrates the challenges of education in a society where grownups have not been given the opportunity to leave the world of childhood and to enter the world of responsible adults. Education as formation requires the acknowledgement of a division between generations, where education is the place where teachers initiate children into a world that precedes them. In a world where adults are portrayed as either grown-up children, social rejects or mindless followers of rules and opinions, the role of the teacher becomes either unclear or instrumentalized. It becomes unclear insofar as children are already in themselves declared competent and politically capable. It becomes instrumentalized insofar as when formation is divorced from education, what remains is the mere promotion of instrumental skills.

\section{Ricky and Hec: formation in the bush}

During the first months on the run in the bushlands, Hec functions as an excellent but very reluctant teacher in the art of living self-sufficiently in nature. Ricky quickly discovers that he is incapable of surviving on his own. Upon observing Hec's natural ability to survive, he becomes interested in knowing what it takes to do so. Hec reluctantly tells Ricky about what he calls 'the knack.' When pushed to elaborate he gives the following vague explanation: 'It's not a thing. It's just...You just get it. it's a...Oh, It's a way of, uhm, it's a way of figuring things out, without having to think too hard or...or talk, more importantly.' While Hec is unable to verbalize his knowledge he proves quite capable of teaching by examples. ${ }^{5}$ This marks the beginning of Ricky's education in nature, where he slowly acquires 'the knack' by observing and imitating Hec. Simultaneously, Ricky's insistent questions challenges Hec to begin to communicate his tacit knowledge and, what is more, to reflect on his life and his relationship to others and to society at large. While Ricky initially lacks all of the skills necessary to survive in nature, he is part of a cultural world (through books, films and music) that Hec knows nothing about. Even if this tacit knowledge is insufficient (and sometimes even detrimental) in terms of surviving in the bush, it does allow Ricky to reflect on himself and his life from many different vantage points. His communicative abilities gives him

\footnotetext{
${ }^{5}$ For a discussion on Rousseau and teaching by example see McEwan (2011).
} 
access to a social life that $\mathrm{Hec}$ is unable to engage with, being both illiterate and in lack of a sufficiently developed vocabulary. Initially Hec dismisses books as useless items, but increasingly, as his relationship to Ricky deepens, he senses the value of a common language for sharing life with others.

As Ricky is about to reenter society temporarily - reaching out to Kahu and TK in order to find help for the sick ranger - he has begun to acquire 'the knack' from living alongside Hec in the bush. Telling Kahu of his adventures with $\mathrm{Hec}$, he describes their relationship as follows: 'He's like one of the best bushmans in the whole country. He, like, teached me all of his skills, so now we're, like, equal best bushmen in the country. Yeah, we're best friends.' From this point, there is a change in the relationship between Ricky and Hec. As their friendship begins to develop further, Hec's need for the communicative skills necessary for connecting with others becomes increasingly obvious to him. As part of his counseling before arriving at Bella and Hec's, Ricky has been taught to compose haiku poems as a way of expressing his feelings. At first, the haikus serve the instrumental purpose of letting Ricky vent his frustration and anger. However, during the course of his growing friendship with $\mathrm{Hec}$, they become central tools for reflecting on their relationship and for beginning to establish a site for what Biesta (2010) calls subjectification. The first time Hec openly acknowledges this is when he, from having dismissed books as useless, approves of Ricky's newly composed haiku:

Trees, birds, rivers, sky

Running with my uncle Hec

Living forever

Toward the end of the film, after they have surrendered to the authorities and Hec is released from jail and is temporarily housed in a correctional rehabilitation and reintegration home, he sits on the doorstep teaching himself to read. As Ricky - now living with Kahu and TK - arrives, Hec announces that he has written a haiku himself. It reads:

Me and this fat kid

We ran, we ate and read books

And it was the best

With these few lines, $\mathrm{Hec}$ retrospectively acknowledges and verbalizes their mutual transformation. He also, for the first time, accepts his responsibility for Ricky. He is able to do this as his relationship with Ricky has given him a sense of higher purpose as an increasingly morally responsible human being, beyond his self-sufficiency as a 'natural man.' He thereby willingly reenters society, accepting, for the first time, his role as Ricky's 'uncle.' In doing so he is able to turn his contempt into reconciliation. The price they have to pay for reentering society, however, is to give up on the dream of finding freedom in nature. As they are finally cornered by the authorities with no escape in sight, $\mathrm{Hec}$ is forced to surrender his ideals of living outside society 
as he is brutally confronted with the consequences of his actions for Ricky. Even if it means giving up on his own way of life and risking Ricky's disappointment, Hec finally assumes responsibility as an adult and surrenders. In order to maintain a relation with Ricky, Hec needs to adjust to the demands of society even if this means ending their mutual formative journey in the bush. Hec's decision to surrender signals the unsustainability of maintaining relationships between children and adults that are grounded in equal responsibilities. As it turns out, out of concern for Ricky's well-being, Hec is forced to reinstate an order of authority and obedience in order to salvage their relationship and ensure that Ricky can return safely to society.

Formation for Rousseau is about becoming an individual capable of living in society without succumbing to the prejudices of popular opinion. Ricky Baker, being already corrupted by existing society, therefore has to begin his formation by unlearning his old ways modeled after images from popular culture. With Hec guiding him in the ways of the natural man, Ricky's first task is to become self-sufficient in nature. Through examples provided by $\mathrm{Hec}$, he gradually acquires 'the knack,' allowing him a degree of independence in the wild. Having chosen the life of a kind of 'civilized savage,' Hec is initially unable to reintroduce Ricky into society. While Rousseau's Emile is guided by Jean-Jacques through all of the stages of his formation, Ricky and Hec are dependent upon one another to develop the moral maturity needed to finally reenter society. Without recourse to morally responsible adult role models to guide them, Ricky and Hec have to find their own way where they depend on each other's different strengths ( $\mathrm{Hec}^{\prime}$ 's natural abilities to survive and Ricky's ability to self-reflect using literature and popular culture) to help them navigate in unchartered territory. It is possible to interpret the shift in the film from the increasingly mutual formation in the bush to the reintroduction into society as a critical commentary upon the kind of idealized pedagogical relation that Rousseau depicts in Emile, where Jean-Jacques and Emile maintain a sense of stability in their roles as pupil and tutor throughout the many different stages of Emile's education. Unlike Emile, Ricky begins his education with prior experiences and skills that, while some are useless for him in the bush, others prove key for Hec's formation and for their mutual return to society. There is a sense of reciprocity in Ricky's and Hec's formation that is missing from Rousseau's educational practice and that forms a bond of trust necessary for completing the passage from nature to society. Even if it turns out that, in the end, it is crucial for $\mathrm{Hec}$ to resume responsibility, he is only capable of coming to this understanding through his developing relationship with Ricky. It seems then, that Hec can only assume the role of a responsible adult by first acknowledging the reciprocity, but not equality, of his and Ricky's relation.

What, then, are the questions posed by Hunt for the Wilderpeople to a contemporary understanding of education as formation? First, we argue that the film illustrates, with great poignancy, the difficulties of establishing adult authority (necessary for pedagogical relations) in a world where authority appears to be either established through coercion and bureaucracy (embodied in the film by Paula) or abandoned all together in a refusal to assume responsibility for the world and a desire to remain in childhood (embodied in the film by TK). Even so, Hec's transformative journey into a responsible adult shows the possibility of navigating between these 
two extremes. Second, the film also underlines that while, in the end, educational relations require the kind of authority gained through assuming responsibility, this kind of authority can only be established through reciprocity. That is, there is a social dimension to formation pointing to the necessity and difficulty of establishing long-term trust between teacher and child. Without this bond of trust, there can be no real authority, and without authority, there can be no formation.

\section{Reclaiming Education as Formation}

In a contemporary society where the combined effect of changing technologies and the impact of global markets upon employment practices and prospects places the concept of adulthood under stress' (Quill 2011, p. 338), education risks replacing the trust-based authority of the teacher as a responsible adult with the consumer-supplier relation of the market. As Biesta (2005, p. 59) writes, when education is subordinated this logic, 'the only questions that can meaningfully be asked about education are technical questions, that is questions about the efficiency and the effectiveness of the educational process'. Consequently, '[t] he more important questions about the content and purpose of education become virtually impossible to ask, other, that is, than in response to the needs of the learner'. While the 'learnification' of education appears perfectly compatible with the absence of responsible adults, in so far as the pedagogical relation is rendered all but superfluous, education as formation hinges on the trust in the authority of the teacher to take responsibility for the content and purpose of education.

Education without formation risks ending up being not so much about teaching knowledge (aimed at the cultivation of judgment and responsibility) as it is about inculcating whatever skills are currently in vogue. Such skills, however, cannot prepare the way for Ricky and Hec to reenter society as 'no longer one but a part of the unity' (E.1, p. 40). At the same time, it appears impossible to return to a traditional model of the pedagogical relation, based on 'the independent authority it grants to those responsible for the most vulnerable in society' (Friesen 2017, p. 180). From Arendt's point of view, it is impossible to reinstate a traditional kind of pedagogical relation in so far as this relation hinges on a conception of authority that in turn requires a firm foundation in tradition. Because modern society is 'neither structured by authority nor held together by tradition' $(2006,191)$, the contemporary pedagogical relation, and the teacher authority inherent in it, need to be reconceived so as to respond to the changing political landscape of education.

The relationship between Ricky and Hec illustrates the intrinsic reciprocity of contemporary childadult relations. It is interesting precisely because while it grows out of an increasingly mutual process of formation, it can neither be quenched by bureaucracy nor sufficiently expressed through the desire to remain in childhood. That is, while it is impossible to escape the grasp of bureaucracy, as is vividly expressed in the scene where Ricky and Hec are finally cornered by Paula and the authorities, and while the childishness of TK proves insufficient for the continued formation of Ricky, both of these opposites may be interpreted as necessary counter positions to navigate between for Ricky and Hec as they reenter society. Put differently, for education to be conceived as formation in a society characterized by the alignment of the commodification of 
welfare provision and child-centeredness, adult authority needs to be reconceived in terms of a reciprocal relationship without handing over the responsibility for the world to children. However, it is problematic to assume that this challenge can be addressed and countered from the perspective of the individual teacher and the individual child. Instead, what is needed is for educational thought to reengage with the notion of education as formation in the context of the contemporary educational landscape. What this kind of philosophical approach has to offer, is to place the pedagogical relation at the center of attention. In this way, the pedagogical relation becomes the lens through which we might judge and respond to the various challenges of contemporary social and political changes affecting education.

Education as formation hinges on a process of introduction where one generation offers its understanding of the world to the next. If education is narrowly conceived in terms of qualification alone (as Biesta claims that the 'learnification' of education assumes), it is difficult to see how the question of responsibility for a common world may be productively tackled. To undergo formation, in this sense, is to accept the invitation of the teacher to get to know the world better so as to be able to form judgments about it, and to act autonomously upon these judgments. The teacher becomes central because, as Arendt claims, it is the teacher who is appointed the role of the responsible adult par excellence, and who, more than any other adult, is expected to act as a representative of the world to the young. This, in turn, appears to require some measure of distinctness between what it is to be a child and what it is to be an adult. Herein, perhaps, lies the most important pedagogical insight of Hunt for the Wilderpeople. As Ricky and Hec set out on their journey, Hec refuses to assume the role of a responsible adult and Ricky refuses to accept the dependency of childhood. Over the course of their relationship, however, as they begin to develop a sense of reciprocity, they also gradually ease into their respective roles as adult and child. The reciprocity central to a contemporary understanding of formation therefore seems to require a mutual agreement on the inherent asymmetry between childhood and adulthood. The kind of reciprocity cultivated by Ricky and Hec seems hard to reconcile with an educational system characterized by, on the one hand, a relationship where teachers provide services for the consumer-student, and on the other hand, where the progressive ideal of childcenteredness undermines the kind of authority that is the mark of a responsible adult.

\section{References}

Arendt, H. (2006) The Crisis in Education. In Between Past and Future: Eight Exercises in Political Thought (New York: Penguin).

Author

Biesta, G. (2005) Against Learning: Reclaiming a Language for Education in an Age of Learning. Nordisk Pedagogik Vol. 25, pp. 54-66.

Biesta, G. J. J. (2010) Good Education in an Age of Measurement: Ethics, Politics, Democracy (Boulder: Paradigm Publishers). 
Boes, T. (2006) Modernist Studies and the Bildungsroman: A Historical Survey of Critical Trends. Literature Compass 3/2, pp. 230-243.

Buckley, J. H. (1974) Season of Youth: The Bildungsroman from Dickens to Golding (Cambridge, MA: Harvard UP).

Canovan, M. (1983) Arendt, Rousseau, and Human Plurality in Politics. The Journal of Politics, 45(2), pp. 286-302.

Cohen, J. (2010) Rousseau: A Free Community of Equals (Oxford: Oxford University Press).

Darling, J. (1994) Child-Centred Education and its Critics (London: Paul Chapman).

Darling, J \& Nordenbo, S. E. (2003) Progressivism. In: N. Blake, P. Smeyers, R. Smith \& P. Standish (eds.) The Blackwell Guide to the Philosophy of Education (Malden, MA: Blackwell Publishing), pp. 288-308.

Dilthey,W. (1985) Poetry and Experience (Ed. and trans. R. A. Makkreel and F. Rodi) (Princeton: Princeton UP).

Euben, P. (2001) Hannah Arendt on Politicizing the University and Other Clichés. In: M. Gordon (ed.) Hannah Arendt and Education: Renewing Our Common World (Boulder: Westview Press), pp. 175-199.

Friesen N. (2017) Radicalizing the Pedagogical Relation: Passion and Intention, Vulnerability and Failure. In: M. Brinkmann, M. Buck \& S. Rödel (eds) Pädagogik - Phänomenologie.

Phänomenologische Erziehungswissenschaft, vol 3. (Wiesbaden: Springer VS).

Jonas, M. E. (2010) When Teachers Must Let Education Hurt: Rousseau and Nietzsche on Compassion and the Educational Value of Suffering. Journal of Philosophy of Education, 44(1), pp. 45-60.

Kitchen, W. H. (2014) Authority and the Teacher (London: Bloomsbury).

Levinson, N. (2010) A 'More General Crisis': Hannah Arendt, World-Alienation, and the Challenges of Teaching for the World As It Is. Teachers College Record, 112(2), pp. 464-487.

McEwan, H. (2011) A Portrait of the Teacher as Friend and Artist: The Example of Jean-Jacques Rousseau. Educational Philosophy and Theory, 43(5), pp. 508-520.

Mintz, A. I. (2012) The Happy and Suffering Student? Rousseau's Emile and the Path not Taken in Progressive Educational Thought. Educational Theory, 62(3), pp. 249-265.

Nichols, M. P. (1985) Rousseau's Novel Education in the Emile. Political Theory, 13(4), pp. 535558.

Plamenatz, J. (1972) Rousseau: The Education of Emile. Journal of Philosophy of Education, 6(2), pp. 176-192. 
Quill, L. (2011) The Disappearance of Adulthood. Studies in Philosophy and Education, 30(4), pp. 327-341.

Rousseau, J-J. (1979) Emile or On Education, ed, trans. Allan Bloom (New York: Basic Books).

Rousseau, J-J. (2012) The Social Contract. In John T. Scott (ed. and trans.) The Major Political Writings of Jean-Jacques Rousseau (Chicago: University of Chicago Press).

Tröhler, D. (2011) Languages of Education: Protestant Legacies, National Identities, and Global Aspirations (London: Routledge).

Tröhler, D. (2012) Rousseau's Emile, or the Fear of Passions. Studies in Philosophy and Education, $31(5)$, pp. 477-489.

Villa, D. (2017) Teachers of the People: Political Education in Rousseau, Hegel, Tocqueville, and Mill (Chicago: The University of Chicago Press).

Waititi, T. (dir.) (2016) Hunt for the Wilderpeople (The Orchard).

Winch, C. (1996) Rousseau on Learning: A Re-evaluation. Educational Theory, 46(4), pp. 415-428.

Yonah, Y. (1993) The Quest for the Good Life in Rousseau's Emile: An Assessment. Studies in Philosophy and Education 12, pp. 229-243. 